\title{
INTERNET, IDENTITY AND ISLAMIC MOVEMENTS: THE CASE OF SALAFISM IN INDONESIA
}

\author{
A. M. Iqbal \\ Asia Research Centre, Murdoch University, Perth, Australia \\ iqbal0912@gmail.com
}

\begin{abstract}
The revolution of information and communication technology has transformed the world into different shape, including Muslim world. This technology in the form of internet does not merely have the democratizing potential for Muslim world, but also has created a new public sphere and new Islamic authority. This paper discusses the role of internet as played by Muslim religious movement, especially Salafism in Indonesia. Using textual analysis of data collected from their websites, this article argues that the internet as modern technology of information and communication has helped Salafism rise to the public to show their ideological and doctrinal stances as well as to challenge their enemies such as Liberal Islam Network (Jaringan Islam Liberat), Shiah, and so on. Through the internet too, this movement respond to such contemporary issues as terrorism, earthquake and others. This means that although orthodox in doctrine and attitude, this movement can benefit from the internet very much for its missionary purposes.
\end{abstract}

Keywords: Internet; Islamic Movements; Salafism; Indonesia

\section{INTRODUCTION}

The revolution of Information and Communication Technology has been transforming the face of the Muslim world within the last decade. The explosion of new media, particularly the internet, has created the global rise of "cyber-Islamic environment" and "Islamic information revolution." A substantial number of studies have been conducted to explain this emerging field of cyber Islam in the last decade. Most of these studies have been devoted to explain how the internet has impacted on Islam, Muslims, and

\footnotetext{
${ }^{1}$ Gary R. Bunt, Islam in the Digital Age: E-jihad, Online Fatwas and Cyber Islamic Environments (London: Pluto Press, 2003).

${ }^{2}$ Gary R. Bunt, "Towards an Islamic Information Revolution?" Muslims and the News Media, ed. Elizabeth Poole and John E. Richardson (London: I.B. Tauris, 2006).
} 
Muslim states. Scholars assert that "digital revolution"3 transforms global Muslim networks, ${ }^{4}$ changes the public sphere in Muslim countries and the West for Muslim minorities, ${ }^{5}$ and empowers the powerless and marginalized groups such as Muslim women. ${ }^{6}$

Other scholars emphasize the democratizing potential of the internet for the Muslim world in that the new media has created a new Islamic public sphere and new Islamic authority that undermine traditional structures of religious authority. ${ }^{7}$ The internet has challenged state authority and authoritarian regimes in the Middle East, ${ }^{8}$ and even has contributed to the success of revolution in the Middle East. ${ }^{9}$

Undoubtedly, such literature has provided important insights into the role and impact of the global rise of cyber-Islamic environments on Muslim societies and states. However, it seems that the subject of inquiry of the existing studies has been mainly focused on the issues of terrorism, radicalism and Islamic politics from the perspective of security studies. ${ }^{10}$

\footnotetext{
${ }^{3}$ Ali Mazrui and Alaim Mazrui, "The Digital Revolution and the New Reformation," Harvard International Review, 23: 1 (2001): 52-55.

${ }^{4}$ Stefano Allievi and Jorgen Nielsen, Muslim Networks and Transnational Communities in and Across Europe (Leiden: Brill, 2003).

${ }^{5}$ Dale F. Eickelman and Armando Salvatore, "The Public Sphere and Muslim Identities," European Journal of Sociology, 43: 1 (2002): 92-115; Bunt, “Towards an Islamic Information Revolution?"; Peter Mandaville, "Reimagining the Ummah? Information Technology and the Changing Boundaries of Political Islam," Islam Encountering Globalization, ed. Ali Mohammadi (London: RoutledgeCurzon, 2002); idem, Global Political Islam (London: Routledge, 2007).

${ }^{6}$ Alexis Kort, "Dar-al-cyber Islam: Women, Domestic Violence and the Islamic Reformation on the World Wide Web," Journal of Muslim Minority Affairs, 25: 3 (2005): 363-383; Fatima Mernissi, "The Satellite, the Prince, and Shaherazad: Women as Communicators in Digital Islam," On Shifting Ground: Muslim Women in the Global Era, ed. F. Nouraie-Simone (New York: The Feminist Press, 2005); Bernardi, Chiara. "Saudi Bloggers, Women Issues and NGOs," Arab Media and Society, 11 (2010).

${ }^{7}$ See, for example, Jon W. Anderson, "New Media, New Publics: Reconfiguring the Public Sphere of Islam," Social Research, 70: 3 (2003): 887-906; Mohammed El-Nawawy and Sahar Khamis, "Divergent Identities in the Virtual Islamic Public Sphere: A Case Study of the English Discussion Forum 'Islamonline," Journal of Arab and Muslim Media Research, 5: 1 (2012); Bunt, Islam in the Digital Age; Vit Sisler, "The Internet and the Construction of Islamic Knowledge in Europe," Masaryk University Journal of Law and Technology, 1: 2 (2007); Nabil Echchaibi, "From Audio Tapes to Video Blogs: The Delocalisation of Authority in Islam," Nations and Nationalism, 17: 1 (2011): 25-44.

${ }^{8}$ Liora Hendelman-Baavur, "Promises and Perils of Weblogistan: Online Personal Journals and the Islamic Republic of Iran," MERIA: The Middle East Review of International Affairs, June 2007; Pardis Mahdawi, "Meeting, Mating, and Cheating Online in Iran," ISIM Review, 19 (2007); Sadiq M. Sait, et. al., "Impact of Internet Usage in Saudi Arabia: A Social Perspective," International Journal of Information Technology and Web Engineering, 2: 2 (2007); Deborah L. Wheeler, The Internet in the Middle East: Global Expectations and Local Imaginations in Kuwait (Albany: State University of New York Press, 2006).

9 Khamis Khamis and Katherine Vaughn, "Cyberactivism in the Egyptian Revolution: How Civic Engagement and Citizen Journalism Tilted the Balance," Arab Media and Society, 14 (2011). Available at: http://www.arabmediasociety.com/?article=769; Sean Aday, et. al., New Media and Conflict after the Arab Spring (Washington: United States Institute of Peace, 2012); Miriyam Aouragh, "Tweeting Like a Pigeon: The Internet in the Arab Revolutions," CyberOrient, 6: 2 (2012); Aziz Douai, "'Seeds of Change' in Tahrir Square and Beyond: People Power or Technological Convergence?" American Communication Journal, 15: 1 (2013); Philip N. Howardand Muzammil M. Hussain, Democracy's Fourth Wave? Digital Media and the Arab Spring (Oxford: Oxford University Press, 2013).

${ }^{10}$ Douai, "'Seeds of Change' in Tahrir Square and Beyond;" El-Nawawy and Khamis, "Divergent Identities in the Virtual Islamic Public Sphere;" Khamis and Vaughn, "Cyberactivism in the Egyptian Revolution;" Dana Janbek, "The Use of the Internet as a Communication Medium by Extremist Muslim Groups: A Content Analysis of Websites," Open Access Dissertations (2009). Available at: http://scholarlyrepository.miami.edu/oa_dissertations/273; Shima D. Keene, "Terrorism and the Internet: A Double-edged Sword,” Journal of Money Laundering Control, 14: 4 (2011): 359-370.
} 
The strategic interests in the global "War on Terror" may have contributed to the scholars and security analysts' serious attention to the relationship between new media and Islamic politics and radicalism in the Muslim world and Western countries where Islam is minority religion. As a consequence, issues other than terrorism and political Islam have not been adequately explored. For example, little research has been conducted to examine the relationship between transnational Islamic movements and the internet, except the ones that focus on terrorist and radical organizations like alQaeda. ${ }^{11}$

Moreover, the predominant focus of the literature has been on cyber-Islam in the Middle East or Arab world ${ }^{12}$ and Muslim minorities in the North America and Europe. ${ }^{13}$ Linguistically, the current research on the internet and Islam is mostly limited to Arabic and English websites, social media or internet forums. Few studies have been conducted by academic scholars to study cyber Islam in Southeast Asia and Africa ${ }^{14}$ Yet, most of these works still focus on the predominant subject of inquiry of the current research on cyber Islam, namely Islamic radicalism and new media. ${ }^{15}$

Such disregard may be due to the assumption among scholars, either Muslims or non-Muslims, and public, which is articulated by media, that

${ }^{11}$ George Michael, “Adam Gadahn and Al-Qaeda's Internet Strategy,” Middle East Policy, 16: 3 (2009): 135-152; Michael Kenney, "Beyond the Internet: Mētis, Techne, and the Limitations of Online Artifacts for Islamist Terrorists," Terrorism and Political Violence, 22: 2 (2010): 177-197; Keene, "Terrorism and the Internet."

${ }^{12}$ Rasha A. Abdulla, The Internet in the Arab World: Egypt and Beyond (New York: Peter Lang Publishing, 2007); Mahjoob Zweiri and Emma Murphy, The New Arab Media: Technology, Image and Perception (Ithaca: Ithaca Press, 2010).

13 Mandaville, "Reimagining the Ummah?;" Poole, Elizabeth. "Networking Islam: The Democratising Potential of New Technologies in Relation to Muslim Communities," The Public, 9: 1 (2002): 51-64; Göran Larsson, "The Death of a Virtual Muslim Discussion Group: Issues and Methods in Analyzing Religion on the Net," Online-Heidelberg Journal of Religions on the Internet, 1: 1 (2005); Patrick Martin and Sean Phelan, "Representing Islam in the Wake of September 11: A Comparison of US Television and CNN Online Message Board Discourses," Prometheus: Critical Studies in Innovation, 20: 3 (2002): 263-269; Simona Hlavacova, "USbased Islamist Network: Presence in Cyberspace and Online Projects," Masaryk University Journal of Law and Technology, 1: 2 (2007); Smeetha Mishra and Gaby Semaan, "Islam in Cyberspace: South Asian Muslims in America Log In," Journal of Broadcasting \& Electronic Media, 54: 1 (2001): 87-101.

${ }^{14}$ Nadirsyah Hosen, "Online Fatwa in Indonesia: From Fatwa Shopping to Googling a Kiai,' Expressing Islam, Religious Life and Politics in Indonesia, ed. Greg Fealy and Sally White (Singapore: ISEAS, 2008); Muhamad Ali, "The Rise of the Liberal Islam Network (JIL) in Contemporary Indonesia," The American Journal of Islamic Social Sciences, 22: 1 (2005): 1-26; Eva F. Nisa, "The Internet Subculture of Indonesian Face-veiled Women," International Journal of Cultural Studies, 16: 3 (2013): 241-255; Johan Fischer, "“We Shift the Channel When Mahathir Appears': The Political Internet and Censorship in Malaysia," Akademika, 75 (2009): 43-63; Noor Hazarina Hashim, et. al., "Islam and Online Imagery on Malaysian Tourist Destination Websites," Journal of Computer-Mediated Communication, 12 (2007): 1082-1102; Shirley S. Ho, et. al., "Muslim Surfers on the Internet: Using the Theory of Planned Behaviour to Examine the Factors Influencing Engagement in Online Religious Activities, New Media Society, 10: 1 (2008): 93-113; Randolph Kluver and Pauline Hope Cheong, "Technological Modernization, the Internet and Religion in Singapore," Journal of Computer-Mediated Communication, 12 (2007): 1122-1142; John Chesworth, "A study of Selected Islamic Internet Sites in East Africa," Masaryk University Journal of Law and Technology, 1: 2 (2007).

${ }^{15}$ Birgit Brauchler, "Islamic Radicalism Online: The Moluccan Mission of the Laskar Jihad in Cyberspace," The Australian Journal of Anthropology, 15: 3 (2004): 267-285; idem, "Cyberidentities at War: Religion, Identity and the Internet in the Moluccan Conflict," Indonesia, 75 (2003): 123-151; Merlyna Lim, "Islamic Radicalism and anti-Americanism in Indonesia: The Role of the Internet," Policy Studies, 18 (2005); Hui, Jennifer Yang. "The Internet in Indonesia: Development and Impact of Radical Websites,' Studies in Conflict \& Terrorism, 33: 2 (2010): 171-191. 
Islam is identical to Arab world and Muslims are synonymous with Arab people. Non-Arab Muslims, who constitute the majority of Muslims in the world, are often overlooked because they are considered to be in periphery compared to the Middle East, which is traditionally regarded as "the centre of the Muslim world' from the perspective of Orientalism. This overlooking may have attributed to the "disregard of the Muslim world in East and Southeast Asia"16 or "Ummah in the East," whereas Muslims in Southeast Asia with Indonesia as the largest Muslim country in the world represent the majority of Muslim population.

This article attempts to address these gaps by examining the internet usage by contemporary Islamic movements in Indonesia. For this purpose, it focuses its analysis on Salafism in Indonesia and its embrace of the internet for promoting and articulating collective identity. ${ }^{17}$ This choice was based on, first, it is interesting that although it is theologically considered ultra-conservative, Salafism is technologically a modern movement as seen its eagerness to engage with Information and Communication technologies like the internet, and second, the fact that Salafism is one of the fastest-growing Islamic movements in contemporary Indonesia, a non-Arab Muslim country with the largest Muslim population in the world. The article asks the following principle questions: In what ways are the internet is employed by the Salafists to promote and articulate their collective identity and what is the implication of this usage for their movement?

\section{MATERIALS AND METHODS}

The use of the top search engine Google, which was voted "Most Outstanding Search Engine" and ranked as the preferred search engine by www.searchenginewatch.com and the search terms "Salaf Indonesia" and "Salafi Indonesia" revealed that the online presence of Salafism in Indonesia is seen, among others, in the hundreds of websites operated and maintained by its proponents with links to local and global similar websites. For the purpose of this article, the analysis was focused on a purist Salafi website www.salafy.or.id. The choice was based on that the fact the website represents the mainstream Salafi movement, which was expected to help us understand better the relationship between Islamic movements and new media technology.

The required data were collected through online observation and web archiving of the selected websites. Postings posted by the web

\footnotetext{
${ }^{16}$ Wai-Yip Ho, "Islam, China and the Internet: Negotiating Residual Cyberspace between Hegemonic Patriotism and Connectivity to the Ummah," Journal of Muslim Minority Affairs, 30: 1 (2010): 64.

${ }^{17}$ For the discussion on the origin and the development of Salafism in Indonesia, see ${ }^{17}$ Noorhaidi, "Laskar Jihad: Islam, Militancy and the Quest for Identity in post-New Order Indonesia," PhD Dissertation, The University of Utrecht, 2005.
} 
administrator and contributors were collected from the Salafi website to examine the ways the Salafists use the internet. Such postings were analysed for topic, tone of arguments, and type of response. The methodology involved a textual analysis of the collected postings to uncover categories of the Salafi use of the internet. In this article, the text comprises the Salafi website including articles, postings and images. I allowed the categories to emerge from the collected postings base upon similarities and differences. As Patton said, "the patterns, themes, and categories of analysis come from the data; they emerge out of the data rather than being imposed on them prior to data collection and analysis." ${ }^{18}$

The analysis involved the first step of initial reading of the postings to develop a general sense of their content or a "long preliminary soak" 19 in the web texts, which were suspected as to have answers to the research questions. The next step was to develop categories of the ways the Salafi employ the internet. Then, I reread the postings and articles and placed them into one of the defined categories. When a posting reflected two or more categories, I placed it into a category based on its most appropriate content. The postings and articles were classified in the following way: ideological, polemical, communicative, and contextual uses of the internet. These analytical stages used the original texts in Indonesian. Only material quoted in this article and the title of postings were translated by me into English.

\section{RESULT AND DISCUSSION}

\section{A. The Salafi Use of Internet}

The website www.salafy.or.id belongs to the purist Salafi community, the mainstream Salafism in Indonesian. ${ }^{20}$ It is run by supporters of the purist Salafism in their attempts to articulate Salafi collective identity. This can be seen in the board of supervisors and contributors that come from the authorities of Indonesian branch of purist Salafism such as Muhammad Umar As-Sewed and Luqman Baabduh. The website also extensively posts the writings by the authorities of purist Salafism in the Middle East such as Ibn Baz of Saudi Arabia and Rabi al-Madkhali of Yemen and its local contributors largely make them the main references for their articles. All this is consistent with a report by International Crisis Group ${ }^{21}$ and a study

\footnotetext{
${ }^{18}$ Cited in Linda A. LaSalle, "Exploring Campus Intolerance: A Textual Analysis of Comments concerning Gay, Lesbian and Bisexual People," A paper presented at the Meeting of the American Educational Research Association, San Francisco, April 1992.

${ }_{19}$ Federico Pablo Feldstein and Caroline Acosta-Alzuru, "Argentinean Jews as Scapegoat: A Textual Analysis of the Bombing of AMIA,” Journal of Communication Inquiry, 27 (2003): 152-170.

${ }^{20}$ For further information and analysis of other Salafi groups, see Wiktorowicz (2004), Noorhaidi, "Laskar Jihad;" and Hasan, "The Salafi Movement in Indonesia," 83-94.

${ }^{21}$ International Crisis Group, "Indonesia Backgrounder: Why Salafism and Terrorism Mostly Don't Mix', Asia Report, 83 (2004).
} 
by Noorhaidi ${ }^{22}$ and Hasan ${ }^{23}$ that the purist Salafis of Indonesian branch established www.salafy.o.id as their own website.

The website was designed as a mainly text-based and easy-to-use website with light green (believed to be a representative colour of Islam) as its background colour. Its homepage displays a title of the website 'Salafy Online Situs Salafi Ahlussunah wal Jamaah' (Salafi Online, the website of the followers of Sunnah and Community), the term "As-Salafy" written in Roman and Arabic scripts, and a subtitle "Meniti jejak al-salaf al-salih" (Following the footsteps of the Pious Forefathers). Using Indonesian as the main language, the website appears in the following main structure: First, main menu that contains sections "Home", "Tentang Kami" (About Us), "Mengapa Harus Salafy" (Why Should be Salafy), "Info Kajian Salafy" (Information about Salafi Studies), "Arabic Tool", "Download Centre", "Forum Kita (Our Forum), "Free Webmail", and "Kontak Kami" (Contact Us). Second, articles that are categorized as "Aqidah" (faith), "Manhaj" (method), "Fiqh" (Islamic jurisprudence), "Fatwa-fatwa" (fatwăs: religious opinions), and "Info Dakwah" (Information about Islamic mission). Lastly, links and affiliations that connect the Salafi website to other local and global Salafi websites.

The articles posted on the website were written in Indonesian by Indonesian purist Salafi figures such as Umar Sewed, Luqman Baabduh, and Abu Hamzah with references to the global Salafi authorities in the Middle East. The website also includes the translated writings and fatwās by the Middle Eastern Salafi authorities such as Muhammad Nashir al-Dīn al-Albānī, Rabī' al-Madkhali, 'Abd Allāh bin Baz, Shaykh 'Uthaymin, Muqbil al-Wadi' 'ì, and Fauzān Șāliḥ.

\section{B. Promoting Salafi Ideology}

There is no doubt that the Salafi community uses the internet as a medium for promoting their Salafi identities. The website's statement reveals that the Salafi community regards the internet as a medium of da'wa Salaf (Salafi mission) aimed at propagating and communicating the Salafi identities (see "Tentang Kami" section). First of all, this sort of use is expressed in the utilization of website by the Salafists to post articles and fatwās regarding the basic principles of Salafi ideology including the ways of Salaf, dress code and behaviour, jihad, and politics.

\section{Manhaj Salaf}

The Salafis communicate their Salafi principles by posting articles written by Indonesian Salafis, with the extensive reference to the Middle Eastern Salafi ideologues, and writings by the Middle Eastern Salafi authorities

\footnotetext{
${ }^{22}$ Noorhaidi, "Laskar Jihad."

${ }^{23}$ Hasan, "The Salafi Movement in Indonesia," 83-94.
} 
translated into Indonesian. The postings deal with the manhaj al-salaf alsălih (the way of the righteous predecessors), which is believed as the only right way to understand and implement Islamic teachings. It is believed as the best way of understanding and practicing Islam because they were exemplified by the Prophet Muhammad, his companions (sahābah), those who followed them ( $t \bar{a} b i \cdot i n)$, and a generation after who followed them ( $t^{a} b i^{\circ}$ al-täbi $\left.{ }^{\top} \bar{i}\right)$. They were the predecessors (salaf, singular; asläf, plural), the early generations of Muslims, that were believed to have the best methods in understanding and practicing Islam under the direct guidance of the Prophet.

In their postings, the Salafis assert that their mission is $d a^{6} w a h$ salafiyyah (Salafi propagation) on which their understanding and practices of Islam are based and to which they call other Muslims. This conviction is based on religious texts, the Quranic verses and the Sunnah, that are regarded as to say about the early generations of Muslim as the perfect models of understanding and observing Islam. The most refereed texts include the Quranic verse saying that "Ye are the best of peoples, evolved for mankind, enjoining what is right, forbidding what is wrong, and believing in Allah" (Surah Āli "Imrān: 110) and the Sunnah narrated by Bukhāri and Muslim that the prophet Muhammad said "The best people are my generation, then a generation after, and then a generation after". Therefore, the Salafis believe that they are the saved among various Muslim groups based on their understanding of the Sunnah says "The Jews split up into seventy one sects and the Christians split up into seventy two sects. My people will split up into seventy three sects which all of them are in the Fire, except one in Paradise. It was asked: "Who is that?" he replied: "That which I and my companions are upon" (see "The essence of the Salafi mission', ${ }^{24}$ 'The method of the forefathers ${ }^{25}$ ).

Like most Muslims, the Salafis emphasize that the very core of their mission is a call for tawhid (monotheism; the oneness of God) and avoidance of shirk (polytheism), the main messages of all prophets. They highly emphasize the importance of tawhid in Islamic faith and the danger of shirk (see 'the place and urgency of tawhid in Islam';, 'Beware of shirk' ${ }^{27}$ 'About tawhid ${ }^{28}$ ). But, what distinguishes them from the Muslim majority is their particular strict ways in understanding and practicing the doctrine of tawhid in that they attempt robustly to purify in belief and practice the doctrine from all forms of un-Islamic innovations and influences. They believe that the prophet Muhammad began and finished

\footnotetext{
${ }^{24}$ Original title: 'Hakikat dakwah Salafiyyah'(Indonesian).

${ }^{25}$ Original title: 'Manhaj Salaf'.

${ }^{26}$ Original title: 'Kedudukan tauhid dalam Islam dan urgensinya'.

${ }^{27}$ Original title: 'Awas, bahaya syirik merenggut anda'.

${ }^{28}$ Original title: 'Jenis-jenis tauhid'.
} 
his mission with the tawhid doctrine (see 'Monotheism, the mission of all prophets ${ }^{29}$ ).

In a posted article, the Salafis elaborate the method of Salafism that involves two steps. First, tasfiyyah that refers to purification Islam from bid'ah (innovations). This step encompasses the movement of purifying Islam from all forms of beliefs, thoughts, and practices that have no basis in the religious texts and no precedence in the practice of the prophet and the early Muslim generations. Second step is tarbiyah that involves education of the pure Islam for Muslims. This aims to educate Muslims with the pure Islam and cultivate them to live their lives with the true Islam (see 'The method of the Salafi mission, ${ }^{30}$ ).

By posting articles in their website, the Salafis attempt to promote the idea of al-walà' wa al-barrä, another important element of their ideology. Al-walā' (loyalty; love) means that a Muslim must love, help, and defend the people of tawhìid (true monotheism) and al-barrä' means that he must despise, denounce and desert the people of shirk (associating God with others). This doctrine requires the clear-cut distinction between Muslims and non-Muslim, between the world of believers and that of unbelievers. For the Salafis, the doctrine includes a prohibition for Muslims to imitate non-Muslims's traditions and ways of life such as clothing. They believe that the al-walā', wa al-barrā' doctrine has basis in the religious texts (e.g. the Quran, al-Mumtahanah: 1, 4; al-Mā'idah:51; al-Tawbah: 23; al-Mujāilah: 22) and was practiced by Abraham, the father of monotheistic religions, and Muhammad. But, it seems that the application of al-walà' wa al-barrä' is confined to those who follow or defy the methods of the Salaf as the perceived by the Salafis (see 'al-wala', wa al-barrä' is a necessity';1 'Loyalty and enmity that are required by shariah $1-5{ }^{32}$ ).

\section{Dress code, beards and men-women relationship}

Like other fundamentalist groups, the purist Salafi community are characterised by high discipline in that their behaviours are regulated by strict interpretation of religious texts. Through their website, the Salafis emphasize the importance of following the ways the prophet Muhammad and the early generations of Muslims lived their lives. So, they grow their beards and shave their moustache and persuade Muslims to do so because they believe they are religious obligations written in the valid religious texts and practiced by the prophet and his companions. The Salafi men prefer Arabic style of dress such as jalabiyya (flowing robes), imāmah (turbans), and trousers right to their ankle, and women appear in niqāb

\footnotetext{
${ }^{29}$ Original title: 'Dakwah tauhid, dakwah para nabi dan rasul'.

${ }^{30}$ Original title: 'Metode dakwah salafiyyah'.

${ }^{31}$ Original title: 'Al-wala wal bara, sebuah keharusan'.

${ }^{32}$ Original title: 'Loyalitas dan kebencian yang disyariatkan'.
} 
(flowing black dress and veil) covering their whole body. In the eyes of the Salafis, this is a religious command aimed as a way to distinguish Muslims from pagan people and non-Muslims. Muslims are prohibited from imitating them in any aspects of their life including personal affairs such as beards and dress code (see 'Let your beards grow' ${ }^{33}$ ).

In their website, the Salafis promote a belief that men-women relationship must be regulated by religious rules. Like Muslim majority, the Salafis believe that adultery (zina) is strongly prohibited by God as written in the religious texts. But, they go further to close anything that brings people to commit adultery. So, they strongly oppose 'liberal' relationship between man and woman such as dating and strongly argue for the importance of separation of men and women in public places. Even, they believe that watching TV and films is prohibited as it can persuade people to do adultery (see 'Watch out! Going out is a step to adultery 1-2'34).

\section{Terrorism and jihad}

For the Salafis, the internet has become a medium to repudiate those who wage jihad, but actually use it for their own interests and purposes. In their opinions, those involved in 9/11 attacks and Bali bombings in 2003 and 2005 were not mujāhid (the holy way fighters) or shahid (martyr). Rather, they were terrorists who created disorder, damage and disruption among society and had nothing to do with jihad as required in Islam. The Salafis call them the narrow-minded people and the ignorant of the true jihäd. Referring to Shaykh Ibn 'Uthaymin of Saudi Arabia, one of the main Salafi authorities, the Salafis assert that jihad cannot reduced to a single understanding as it has multiple meanings. First, jihād al-nafs (self-jihād): conquering one's self in one's attempts by earning religious knowledge to obey God's command and oppose those who call against Him. Second, jihād al-munäfiqīn: fighting against hypocrites with true religious knowledge, not weapon. Lastly, jihäd al-kuffär. fighting against unbelievers who attack Muslim territory and declare a war to Muslims (see 'Islamic perspective of terrorism' ${ }^{35}$; 'Misunderstanding jihāad' ${ }^{36}$ ).

The Salafis argue further that jihād in terms of waging a war cannot be declared unless it meets the required conditions. First, when a Muslim is facing an enemy in a battlefield. Second, when a Muslim country is under attack by enemy. Third, the imām (the leader of Muslim country) declares the jihad and commands all Muslims to do so. Finally, when armed jihad is regarded as a necessity solution under certain conditions and considerations. The Salafis believe that current Muslim world does not

\footnotetext{
${ }^{33}$ Original title: 'Biarkan jenggot anda tumbuh'.

${ }^{34}$ Original title: 'Awas! Pacaran = mendekati zina 1 and 2'.

${ }^{35}$ Original title: 'Makna terorisme dalam pandangan Islam'.

${ }^{36}$ Original title: 'Salah kaprah dalam jihad'.
} 
meet the required conditions to wage a military jihad and those who were involved in violent attacks on non-Muslims are not mujahid, but rather terrorists. Hence, these people, for the Salafis, are not the followers of the manhaj al-salaf, a method implemented by the Prophet and the early Muslim generations, in understanding and practicing jihad (see 'Disclosing the thoughts of a master of terrorism, ${ }^{37}$; 'How to respond properly to Bali bombing, ${ }^{38}$; 'They are terrorists ${ }^{\text {,39 }}$ ).

\section{Politics}

Through their website, the Salafis also disseminate their political ideas. They believe that those who get involved in politics as a means to establish an Islamic state are not the followers of the Salaf. They argue that ideological basis used by these people to justify their political activities is a forbidden religious innovation (bid'ah) that has no precedence in the practice of the Prophet Muhammad and the first generations of Muslims. This ideology, known as tawhid hakimiyyah, refers to a belief that hakimiyyah (sovereignty) belongs only to Allah and governance can only be ascribed to Him so that it is one of the main elements of tawhid (true monotheism). The Salafis reject this conception arguing that it is a bid'ah created as a political weapon to support the political tendency of the politico Salafi groups such as Ihkwan al-Muslimin. Such a doctrine implies the necessity of takfir (declaring a Muslim as an infidel), a doctrine that is also rejected by the Salafis. To support their argument, the Salafis employ a fatwa issued by Hai' ah Kibar al-Ulama (The committee of prominent Salafi ulama) of Saudi Arabia saying that tawhid hakimiyyah is a bid'ah that no one of ahl al-sunnah (the supporters of Sunnah) agrees with it (see 'There is no such a tawhid hakimiyyah in Islam'40; 'More about tawhid hakimiyyah' ${ }^{41}$ ).

The apolitical stance of the purist Salafis is seen in their postings regarding the doctrine of the prohibition of rebellion against a ruler. According to the Salafis, it is a religious obligation for Muslims to "listen to and obey" a ruler, no matter he is good or bad, just or unjust, as long as he does not order to oppose against the God's laws. Muslims are not allowed to oppose the ruler of a country where they can observe their faith peacefully. They argue that any forms of opposition against a ruler ranging from criticism, demonstration to rebellion are illegal religious innovations (bid'ah) that have no precedence in the religious texts and practice of the first generations of Muslims (Salaf). Following a ruler constitutes obedience to Allah and the Prophet Muhammad (Quran Surah al-Nisa: 59).

\footnotetext{
${ }^{37}$ Original title: 'Membongkar pemikiran sang Begawan teroris'.

${ }^{38}$ Original title: 'Menyikapi bom Bali'.

${ }^{39}$ Original title: 'Mereka adalah teroris'.

${ }^{40}$ Original title: 'Tidak ada istilah tauhid hakimiyyah/mulkiyyah dalam pandangan Islam'.

${ }^{41}$ Original title: 'Lagi, tauhid mulkiyyah/hakimiyyah bukan dari Islam'.
} 
Instead of rebellion, Muslims should give advice in private and pray for a ruler of a country who ruled unjustly as practiced by the companions of the prophet, the followers of Sunnah and the Salafi authorities (see 'The religious obligation of compliance with God, the prophet and the ruler' ${ }^{42}$; 'The religious law of rebellion - a obligation of giving advice to a ruler ${ }^{\text {'4 }}$ ).

Therefore, it is seen in other postings that the Salafis reject political activities aimed at taking over of a country and establishing an Islamic state as promoted by the politico-Islamic fundamentalist movements such as Ikwan al-Muslimin and Hizb ut-Tahrir. They argue that such political activities are un-Islamic and forbidden religious innovations (bid'ah) because these will likely bring about disorder and great disadvantages to Muslims such as the government restriction of observing their faith. In addition, the argument that taking over a country is necessary when its ruler does not apply Islamic law is flawed as it resulted from the politicofundamentalist groups' misunderstanding of Islamic state. Referring to Ibn Taymiyya (1263-1328), the main early Salafi ideologue, the Salafis believe that a country can be regarded as an Islamic state if Muslims constitute the majority and they preserve and observe their Islamic faith in public as well as in private. It is the presence of Muslims as majority, not political system, which determines a country to be regarded as an Islamic state. An Islamic state can be a republic country like Indonesia or monarchy like Saudi Arabia. In this case, the Salafis assert, Muslims are ordered to cooperate with the ruler and prohibited to oppose against him as exemplified by the practice of the early Muslim generations (see 'Caliphate as practiced by the prophet' ${ }^{44}$; 'Constructing a true Islamic caliphate ${ }^{45}$.

\section{Waging War against Enemies Online}

The Salafis seem to use the internet as a place to wage a war against those regarded as their eternal enemy. Cyberspace has become a new place of cyberwars in which off-line enmity and conflict are extended online. Through their website, the Salafis criticise and condemn Muslim individuals or groups believed as to have violated the purist version of manhaj al-salaf (the method of the pious forefathers) in understanding and practicing Islam. Their attacks are not only targeted to Muslim groups regarded as not the supporters of Salafism, but also to those who proclaimed themselves as the Salafis.

\section{Shi 'ah}

It appears that the Salafis employ the internet as an effective medium to attack Syi'ah Muslims (Shiites). In the eyes of the Salafis, the Syi'ahs are

\footnotetext{
${ }^{42}$ Original title: 'Perintah taat kepada Allah, Rasul dan pemerintah'.

${ }^{43}$ Original title: 'Hukum memberontak- perintah menasehati penguasa'.

${ }^{44}$ Original title: 'Khilafah di atas manhaj nubuwwah'.

${ }^{45}$ Original title: 'Mendirikan khalifah islamiyah dengan benar'.
} 
not true Muslims as they have allegedly violated some principles of the pristine Islam. They reject the Shiite doctrine of taqiyyah, a doctrine that a Muslim can conceal his or her faith before those regarded as enemy including other Muslims in order to preserve his or her faith and prevent himself or himself from harmful treatment. For the Salafis, the doctrine is a violation of the true meaning of taqiyyah in that concealing one's faith can only be taken before unbelievers who will likely put him or her in danger if she or he reveals his or her faith. Moreover, the Syi'ah attitude of disguising faith before other Muslims (non-Syi'ah) indicates that they are not true Muslims, but hypocrites (munafiqin). To support their attack, the Salafis use particular Quranic verses (al-Nisa: 97-98; Alu Imran: 28; al-Nahl 106), which they believe deal with true taqiyyah, and refer to their ideologues such as Ibn Taymiyyah (see 'Disclosing the Syi' ah: taqiyyah'46).

The Salafis also posted articles condemning the Syi'ah belief in mut'ah, a doctrine that a Muslim is permitted to marry a woman, Muslim or non-Muslims, for a period of time, and the infallibity of their imams (supreme spiritual leaders). They regard the Shi'ah as not the followers of the nash (religious texts) as they allegedly have changed the Quran and Sunnah for their interests and purposes. The Salafis also believe that Syi'ah are not the followers of the Salaf and accuse them of spreading hatred and lies about the Salaf, the Prophet's wives and his companions. Due to these violations, the Salafis conclude that it impossible to establish a dialogue and rapprochement between the Syi'ah and the Sunni Muslims (see series 'Disclosing the Syi'ah: mut'ah marriage'; 'Worshipping imams'; 'Hatred against the Prophet's wives'; 'Fake love of the Prophet's family (ahl albait)'; 'Denigrating the Prophet's companions (sahabah)'; 'A rejection of the Syi' ah doctrine of Mahdi ${ }^{47}$ ).

\section{Jaringan Islam Liberal (JIL)}

The Salafis posted some articles in their website aimed at attacking Jaringan Islam Liberal (JIL; Liberal Islam Network). ${ }^{48}$ For the Salafis, the idea of religious pluralism promoted by the members of JIL seriously contravenes a principle that Islam is the only religion accepted by God. In their attempts to unmask what they believe as the JIL's lies, the Salafis refer to the religious texts saying Islam as the final chain of the religious

\footnotetext{
${ }^{46}$ Original title: 'Membongkar kesesatan Syiah: Taqiyyah'.

${ }^{47}$ Original series titles: 'Membongkar kesesatan Syiah: nikah mut'ah'; 'Memuja imamnya'; 'Benci pada istri Nabi'; 'Cinta palsu pada ahlul bait'; 'Menghina sahabat Nabi'; 'Al-Quran diubah-ubah'; "Bantahan singkat terhadap keyakinan Syiah tentang Mahdi').

48 Jaringan Islam Liberal (the Liberal Islam Network) is a network of young Indonesian intellectuals and activists that promote a new interpretation of Islam characterized by following insights: belief in the openness of ijtihad (personal or collective (re) interpretation of the religious texts); the relative, open, and plural truth; emphasize on the ethical- religious spirit, not the literal meaning of the text; support for minorities and the oppressed; and freedom of belief and faith. For details see N.T. B. Harjanto (2003); Hooker (2004) Ali (n.d.); Nurdin (2005).
} 
transmissions. They argue that Islam as the last revelation encompasses all religions brought by previous prophets such as Judaism and Christianity. This is not only mentioned in the Quran and Sunnah, but also supported by the first Muslim generations and the Salafi authorities. In other words, they claim Islam is the only true religion so that the idea which promotes a religious unity and calls for a common platform among various religious adherents is undoubtedly unacceptable. They call those who support religious pluralism, such as the members of JIL, tăghut (evil) due to their lost of faith in the doctrine of al-wala ', wa al-barrä' (loving and supporting the fellow Muslims, and deserting and showing enmity to unbelievers) (see 'Uncovering the mask of JIL, Ahlus Sunnah shut their mouth'49).

In their postings, the Salafis also label the members of JIL as the followers of evil (shayțān), the servant of reason ('aqI), neo-Mu'tazilites, and the supporters of the method of unbelievers (kuffar) due to their use of reason to understand and interpret texts (nașs) of the Quran and Sunnah, rather than the methods practiced by the Salaf. They consider religious pluralism promoted by JIL as "cheap and obsolete ideology" and a blasphemy to Islam. For the Salafis, the members of the JIL are undoubtedly the supporters of forbidden bid'ah and constitute the JewishChristian conspiracy to destroy Islam and Muslims. As a result, they encourage the ruler of Islamic country to bring the members of JIL to court and sentence them to death, if necessary, due to their blasphemous thoughts of Islamic principles (see series of 'Uncovering the mask of JIL: 'the followers and the worshippers of evil'; 'A call for a religious unity'; 'the true unity of the Salaf'; 'Open trial of JIL ${ }^{, 50}$ ).

\section{Hizbut Tahrir (HT)}

The cyberwar is also directed to Hizbut Tahrir (HT; the Liberation Party), a transnational fundamentalist movement whose operating arena is politics. The Salafis point out that supporters of Hizbut Tahrir are not the true followers of the Quran and Sunnah though they claim that they operate under the guidance of the two main sources of Islam. They are mistaken, the Salafis assert, in that they defy the method of the Salaf as seen in their goals and methods to achieve them. The Hizbut Tahrir use of politics to establish a global Islamic state (khiläfah islämiyyah) brings the Salafis to accuse them of ignoring the prophet's method of Islamic propagation. In his mission, the Prophet called people to the true monotheism (tawhid) and submission to Allah ('ibādah), not to political takeover of the existing authority or the establishment of the Islamic caliphate. Political victory is not a goal of the Islamic propagation, but rather as a necessary result of the

\footnotetext{
${ }^{49}$ Original title: 'Membongkar kedok JIL, Ahlus sunnah membungkamnya'.

${ }^{50}$ Original titles: series articles 'Membongkar kedok JIL: 'Pengikut dan pemuja iblis'; 'seruan penyatuan agama'; 'Persatuan hakiki ala Salaf'; 'Pengadilan terbuka atas mereka').
} 
establishment of society that guided by the Quran and Sunnah. Hizbut Tahrir, according to the Salafis, has ignored the core of Islamic mission (a call for tawhid), and prioritized its periphery (politics and Islamic state) (see 'Politics that prescribed by shariah, a repudiation of HT' ${ }^{51}$; 'The prophets' method of propagation, a repudiation of HT; ${ }^{52}$ 'Uncovering the veil of Hizbut Tahrir. ${ }^{53}$

Their postings reveal that Salafis also attack the high political tendency of Hizbut Tahrir. The Salafis view this ideology as a result of Hizbut Tahrir's misperception of Islamic state. They argue that Islamic state is not a territory in which Islamic law is applied to all aspects of society such as political system and governance as Hizbut Tahrir believes. Rather, it is a country where Muslims constitute the majority and they observe their religion faithfully, no matter what kind of political system and governance is applied. So, the assumption promoted by the supporters of Hizbut Tahrir that there is no currently Islamic state (dār al-Isläm) so that it is a religious obligation to establish an Islamic caliphate expresses their ignorance of the Quran, Sunnah and the manhaj al-salaf (see 'Unmasking Hizbut Tahrir - who is it?' ${ }^{54}$; 'Terorism in the Islamic perspective- a refutation of HT. ${ }^{55}$

The Salafi attack is further directed to Hizbut Tahrir's reluctance of acknowledging hadith ăhād, a kind of hadith (sayings and practices of the Prophet Muhammad) that reported by a single companion of the Prophet (sahābah), as a valid religious source of Islamic doctrines. Referring to a fatwa by Shaykh al-Albani, the Salafis stress that this doctrine is a denigration of the saha $\bar{b} a h$ as part of the Salaf whose credibility is not questioned. This also indicates that the supporters of Hizbut Tahrir have developed religious innovations (bid'ah). Instead of following the method of the Salaf in understanding the hadith, Hizbut Tahrir has followed the method of $\mathrm{Mu}^{6}$ tazilah that prioritizes reason over faith (īmān) in understanding religious texts (see 'Fatwa tentang kesesatan Hizbut Tahrir'; 'Siapakah Hizbut Tahrir?'; 'Bantahan ilmiyyah atas kesesatan akidah HT'). The Salafis also condemn the Hizbut Tahrir for their cooperation with Muslim groups who have defied the method of the Salaf such as Shi'ah saying that it is an expression of their lack of al-walà' wa al-barrä' (a doctrine that a Muslim must love and support fellow Muslims, but desert and show enmity to unbelievers) (see 'Uncovering the mask of Hizbut Tahrir' ${ }^{56}$ ).

${ }^{51}$ Original title: 'Politik yang syar'i- bantahan atas HT'.

${ }^{52}$ Original title: 'Manhaj dakwah para nabi- bantahan atas HT'.

${ }^{53}$ Original titles: 'Membongkar selubung Hizbut Tahrir'; 'Membongkar kesesatan Hizbut Tahrir- Khilafah Islamiyah'.

${ }^{54}$ Original title: 'Membongkar kesesatan Hizbut Tahrir'.

${ }^{55}$ Original title: 'Terorisme dalam timbangan Islam- bantahan atas HT'.

${ }^{56}$ Original title: 'Membongkar selubung Hizbut Tahrir II'. 


\section{Ikhwan al-Muslimin (IM)}

In addition, the Salafis employ cyberspace as a place to attack Ikhwan alMuslimin (the Muslim Brotherhood), another transnational fundamentalist Muslim movement originated from Egypt. Their attacks are focused particularly on Sayyid Qutb, the movement's ideologue. Qutb believes that at the moment there is no Muslim society and Islamic country because there is no society or country that appoints Allah as the only ruler, applies Islamic law and lives an Islamic life. He called them a modern version of jahiliyah (ignorant) society, which existed before the coming of Islam in Mecca and was ignorant of the true Islam. He further introduced takfir, a doctrine that the ruler of a country who does not implement Allah's rules in all aspect of community life can be declared as unbeliever so that he can be toppled and replaced by a true Muslim ruler to establish an Islamic state.

By posting articles, the Salafis claim that Qutb's ideas of takfir, modern jāhiliyyah society and Islamic state are clearly misleading. He was mistaken when he said that hâkimìyyah (sovereignty) was an important element of tawhid (true monotheism). For the Salafis, this resulted from Quṭ's misunderstanding of the Muslim's creed of La ilāha illā Allāh (there is no 'ilah' but Allah), in which he reduced the meaning of the word iläh into "the ruler." This is clearly in contrast with the Salaf who interpreted the word as "the only one who has right to be worshiped." For the Salafis, Qutb's ideas represent the thinking of the supporters of bid 'ah and reflect

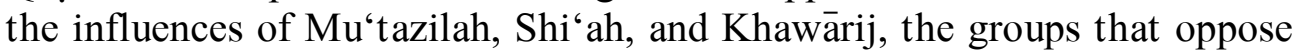
the manhaj al-salaf (see 'The danger of Sayyid Quṭ's idea of takfir ${ }^{57}$ ).

\section{Internal conflict}

It is interesting to note that the Salafis also utilise cyberspace as a place to wage a cyberwar against other Salafi groups, but believed no longer embrace the true Salafi ways. This use shows that the internet is a place where internal conflicts among the Salafi supporters in Indonesia are extended into cyberspace. The fragmentation among the Salafis began when a group of them were accused of being sururis, the supporters of the views promoted by Muhammad ibn Surür, one of the main proponents of politico-Salafis who severely criticised the Saudi government in the case of the presence of American troops in the Arabian soil during the Gulf War. This group developed $d a{ }^{6} w a h$ (propagation) activities by establishing two Salafi foundations, Yayasan al-Sofwah (al-Sofwah Foundation) led by Muhamad al-Khalaf (?) and Majlis al-Turas al-Islami (the Assembly of Islamic Heritage) directed by Abu Nida. These foundations were believed as to have established links with overseas foundations that support Ibn

\footnotetext{
${ }^{57}$ Original title: 'Bahaya pemikiran takfir Sayyid Qutub'.
} 
Surur, namely al-Muntada al-Islami Foundation of London and alJam'iyyah Ihya al-Turats of Kuwait (see 'A testimony of Ustadz

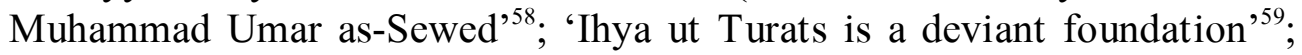
'Disclosing the crimes of Ihya Turas, the enemy of the Salafis' ${ }^{60}$; 'The danger of JI network of Kuwait and al-Turas ${ }^{\text {'61 }}$ ).

Through their website, the Salafis have focused their attacks on these two foundations. Umar as-Sewed in his postings asserts that alSofwah Foundation does not follow the manhaj al-salaf as it is closely affliliated to al-Muntada Foundation of London led by Muhammad ibn Surur. Sewed refers to Syaikh Rabi' al-Madkhaly, a Salafi authority in the Middle East, who said that "if the foundation (al-Sofwah) is similar to alMuntada of London, we think, it will be a major enemy for dakwah Salaf movement in Indonesia". He argues that those involved in al-Sofwah Foundation are not the Salafis because they support Ibn Surur and Ikwan alMuslimin, but they pretend to be Salafis. To supports his arguments, Sewed provides evidence that al-Sofwah's deviation from the manhaj al-salaf is seen in its attempts to publish al-Bayan, a periodical that is published by alMuntada of London, and books written by Sururi authorities, support the activities of groups regarded as ahl al-bid'ah (the supporters of religious innovations) such as Tarekat Sufi, ${ }^{62}$ Ikhwan al-Muslimin, Negara Islam Indonesia (NII), and Partai Keadilan Sejahtera, ${ }^{63}$ and invite the Sururi authorities to give lectures in Indonesia such as Ibrahim al-Duwasy (see 'A testimony of Muhammad Umar as-Sewed ${ }^{64}$ ).

The extension of internal conflict into cyberspace can also be seen in the Salafis' attack on the Majelis al-Turas al-Islamy of Indonesia. The Salafis accuse those involved in the foundation of being deviant from the true method of the Salaf and following the methods adopted by Ikhwan alMuslimin. They are considered as heretics (mubtadi') as they are inclined to support the Sururi ideas by getting themselves involved in political activities and parliament. This is supported by a fact that the foundation has established a network with Jam'iyyah Ihya al-Turas of Kuwait, a foundation that supports the politico-Salafi movement led by Abdul Rahman Abd al-Khaliq. Hence, the Salafis call those who support the Majlis al-Turas of Indonesia 'the puppets (boneka) of Abdur al-Rahman Abd al-Khaliq'. Jamiyyah al-Turas of Kuwait provided Majlis al-Turas with

\footnotetext{
${ }^{58}$ Original title: 'Persaksian al-Ustadz Muhammad Umar as-Sewed'.

${ }^{59}$ Original title: 'Ihya ut Turats menyimpang dalam manhaj'.

${ }^{60}$ Original title: 'Membongkar kejahatan Ihya Turas - musuh Salafiyyin'.

${ }^{61}$ Original title: 'Bahaya jaringan JI dari Kuwait dan al-Turas'.

${ }^{62}$ Sufi Tarekat (Islamic mysticism brotherhood; Sufism; tasawwuf) is a school of thought that promotes the inner or mystical dimensions of Islam. See e.g. Godlas (2000).

${ }^{63}$ PKS (Partai Keadilan Sejahtera [Prosperous Justice Party]) is an Indonesian political party whose ideology is Islam and founded in 1998. It has a close association with Ikhwan al-Muslimin and other campusbased dakwah movements in Indonesia. The party won $7.3 \%$ of the popular vote and 45 out of 550 seats in the 2004 legislative election making it the seventh-largest party in parliament.

${ }^{64}$ Original title: 'Persaksian al-Ustadz Muhammad as-Sewed'.
} 
considerable financial support by which the latter could promote the SururiIkhwani ideology in Indonesia. For the Salafis, the fund allocated by Jamiyya al-Turas of Kuwait has brought about the fragmentation and conflict among the Salafis in Indonesia, which is highly prohibited according to the Quran and Sunnah (see 'Abd al-Rahman Abd al-Khaliq and Ihya al-Turas ${ }^{65}$; ' 'Abd al-Rahman Abd al-Khaliq, a heretic ${ }^{66}$;' 'Questions and answers about Abd al-Rahman Abd al-Khaliq and al-Turas' ${ }^{67}$; 'Ihya alTuras - Ulama do not recommend it ${ }^{\text {"68; }}$ "Ihya al-Turas is a deviant foundation - the puppet of Abd al-Rahman Abd al-Khaliq ${ }^{69}$ ).

Moreover, the Salafis accuse the Ihya al-Turas of Kuwait and Majlis al-Turas al-Islami of Indonesia of having breached the principles of the manhaj al-salaf because of the following reasons. First, they do not obey the ruler as they establish their own system of governance such as pledging an oath to their leaders (bai'at) and developing underground system cells for recruiting particular members who are responsible to particular regions or mosques. Second, the supporters of the two foundations do not follow the Salaf's enmity and isolation (al-bara) of those regarded as the deviants from the manhaj al-salaf as seen in their invitation to these people to give lectures and attend seminars. Finally, those involved in these foundations do not follow the manhaj al-salaf in dealing with the supporters of Salafism (salafiyyin). They do not show their support and love (al-wala) to the ulama of the manhaj al-salaf by not inviting them to give lectures and advice and they bring the salafiyyin into conflict and fragmentation through their funds (see 'Disclosing the crimes of Ihya al-Turas - loyalty to the ruler ${ }^{\text {'70 }}$ ).

Therefore, the Salafis remind the true followers of the Salaf of the danger of these foundations and ban publishers and bookshops to publish and sell works by the supporters of these foundations. To support this, the Salafis refer again to the fatwas issued by the Salafi authorities in the Middle East such as Rabi bin Hadi al-Madkhali, Ubaid al-Jabiri, Muhammad bin Hadi al-Madkhali, and Muqbil bin Hadi (see Fatwas on Ihya al-Turas" ${ }^{71}$; Ihya al-Turas is a deviant foundation - khilafiyah and ijtihaidiyah "72 'An open call for publishers and bookshop owners" ${ }^{73}$; 'Beware of al-Sofwah and Ihya al-Turas ${ }^{74}$ ).

\footnotetext{
${ }^{65}$ Original title: 'Abdurrahman Abdul Khaliq dan Ihya Turas'.

${ }^{66}$ Original title: 'Abdurrahman Abdul Khaliq - seorang mubtadi'.

${ }^{67}$ Original title: 'Soal-jawab tentang Abdurrahman Abdul Khaliq \& at-Turas'.

${ }^{68}$ Original title: 'Ihya Turas - ulama tidak merekomendasi'.

${ }^{69}$ Original title: 'Ihya Turas menyimpang - boneka Abdurrahman Abdul Khaliq'.

${ }^{70}$ Original title: 'Membongkar kejahatan Ihya'ut Turas - taat pemerintah'.

${ }^{71}$ Original title: 'Ihya ut Turas menyimpang dalam manhaj - fatwa ulama'.

${ }^{72}$ Original title: 'Ihya ut Turas menyimpang dalam manhaj - khilaf \& ijtihadiyah'.

${ }^{73}$ Original title: 'Seruan terbuka bagi penerbit dan pemilik toko buku'.

${ }^{74}$ Original title: 'Hati-hati dengan al-Sofwah dan Ihya Turas'.
} 


\section{CONCLUSION}

An examination of the Salafi use of the internet reveals that cultural spaces are affected by the internet through communal processes, in which the Salafi community adopts and adapts the internet to fulfil its religious purposes. In these processes, the Salafis modify the internet and place it in their communal context. Particularly, they adjust the internet through a localization process within the framework of their network and regulations. This works in two ways: while the Salafis localize the global force of the internet, they themselves are being reshaped to become a part of a globalizing world. This interaction represents the processes of "cultured technology," 75 appropriation of the global media and spiritualizing technology, which not only facilitate the Salafis to preserve their existence within their traditional boundaries, but also culturally transform the internet into a new type of technology that serves the needs and interests of the Salafi community.

Through these processes, as seen in their use of the website, the Salafis embrace the internet as a means to communicate and promote their Salafi identities. More specifically, the Salafis use the internet as an ideological tool by which they communicate their fundamentalist ideology and disseminate the Salafi $d a^{6} w a h$ (mission) to wider audiences. It appears that the Salafis employs the internet as a polemical means in that they wage a cyberwar against those are regarded as to have violated the authentic Islam as set by the Salaf (the pious predecessors), such as the Shi'ites, Ikhwan al-Muslimin and Hizbut Tahrir. Cyberspace becomes a new place of cyberwars in which off-line enmity and conflict are extended online. In addition, for the Salafis, internet plays a role as a medium for responding to contemporary issues of local and global societies. Through their website, the Salafis express their views and concerns over global issues such as conflicts and economical and political instability facing countries of the Muslim world as well as local issues such as Tsunami that struck Indonesia in 2004. This reflects the paradox of transnational movements like Salafism; it operates across national borders and challenges the nation-state territorially as well as ideologically, but cannot ignore the current issues of the country where it operates as its attempts to scale up its influences or at least preserve its presence in a local (national) arena. Finally, the Salafi community utilizes the internet for building linkage and networks. They use cyberspace as a medium to maintain solidarity and develop local (national) and global networks among the local and global supporters of Salafism.

${ }^{75}$ Karine Barzilai-Nahon and Gad Barzilai, “Cultured Technology,” The Information Society, 21 (2005): $25-$ 40. 
This indicates that a local Salafi network can have global effects and a global Salafi network can have influences on a local Salafi community.

The ways the Salafis make use of the internet to articulate their identities also exemplify the process of "spiritualizing the internet." Through this process, the Salafis adopt and confer a kind of religious legitimacy on the internet for their spiritual purposes and values. This may involve a process of negotiation between the Salafi religious worldviews and the ethos of the internet as a product of the profane worldviews. As Campbell says, it "highlights that technology is embedded in a social process of negotiation between individuals and groups who inevitably shape them towards their own desire and values." What distinguishes the Salafis, or religious communities in general, from the non-religious groups in this process is that the former endorses and utilizes the new media for their needs and interests within "a spiritually rich worldview with meanings and values that might be absent" in the latter groups (Kluver and Cheong 2007: 1125).

As a case study, the findings of this study may pertain only to the interplay between the Islamic movements and the internet. And as a textual analysis, this study may suffer from the lack of empirical explanation and statistical data. But, I believe that the strength of this study lies most in its depth and its position as a clear evidence of the coexistence between religion and modernization. I also believe that the findings of this study reflect the same patterns of the internet use by most of religious communities.

\section{REFERENCES}

Abdulla, Rasha A. The Internet in the Arab World: Egypt and Beyond. New York: Peter Lang Publishing, 2007.

Aday, Sean, et al. New Media and Conflict after the Arab Spring. Washington: United States Institute of Peace, 2012.

Ali, Muhamad. "The Rise of the Liberal Islam Network (JIL) in Contemporary Indonesia," The American Journal of Islamic Social Sciences, 22: 1 (2005): 1-26.

Ali, Muhamad. "The Internet, Cyber-religion, and Authority: The Case of the Indonesian Liberal Islam Network," Islam and Popular Culture in Indonesia and Malaysia, ed. Andrew N. Weintraub. Abingdon and New York: Routledge, 2011.

Allievi, Stefano and Jorgen Nielsen. Muslim Networks and Transnational Communities in and Across Europe. Leiden: Brill, 2003.

Anderson, Jon W. "New Media, New Publics: Reconfiguring the Public Sphere of Islam," Social Research, 70: 3 (2003): 887-906. 
Aouragh, Miriyam. "Tweeting Like a Pigeon: The Internet in the Arab Revolutions," CyberOrient, 6: 2 (2012).

Barzilai-Nahon, Karine and Gad Barzilai. "Cultured Technology," The Information Society, 21 (2005): 25-40.

Berger, Peter L. "The Desecularization of the World: A Global Overview," The Desecularization of the World: Resurgent Religion and World Politics, ed. Peter L. Berger. Washington: Ethics and Public Policy Center, 1999.

Bernardi, Chiara. "Saudi Bloggers, Women Issues and NGOs," Arab Media and Society, 11 (2010).

Brauchler, Birgit. "Islamic Radicalism Online: The Moluccan Mission of the Laskar Jihad in Cyberspace," The Australian Journal of Anthropology, 15: 3 (2004): 267-285.

" "Cyberidentities at War: Religion, Identity and the Internet in the Moluccan Conflict," Indonesia, 75 (2003): 123-151.

Bunt, Gary R. Islam in the Digital Age: E-jihad, Online Fatwas and Cyber Islamic Environments. London: Pluto Press, 2003.

Bunt, Gary R. "Towards an Islamic Information Revolution?" Muslims and the News Media, ed. Elizabeth Poole and John E. Richardson. London: I.B. Tauris, 2006.

Campbell, Heidi. "Spiritualizing the Internet: Uncovering Discourse and Narratives of Religious Internet Use," Online-Heidelberg Journal of Religions on the Internet, 1: 1 (2005).

Chesworth, John. "A study of Selected Islamic Internet Sites in East Africa," Masaryk University Journal of Law and Technology, 1: 2 (2007).

Dawson, L. L. "Researching Religion in Cyberspace: Issues and Strategies," Religion on the Internet: Research Prospect and Promises, ed. J.K. Hadden and D.E. Cowan. Philadelphia: Elsevier Science Inc.: 2000. . 'Doing Religion in Cyberspace: The Promise and the Perils,' The Council of Societies for the Study of Religion Bulletin, 30: 1 (2001): 3-9.

"The Mediation of Religious Experience in Cyberspace: A Preliminary Analysis," Religion in Cyberspace, ed. M. Hojsgaard and M.Warburg. London: Routledge, 2004.

and D.E. Cowan. Religion Online. London: Routledge, 2004.

Dijk, C. van. Rebellion under the Banner of Islam: The Darul Islam in Indonesia. The Hague: M. Nijhoff, 1981.

Douai, Aziz. "'Seeds of Change' in Tahrir Square and Beyond: People Power or Technological Convergence?" American Communication Journal, 15: 1 (2013). 
Duderija, Adis. "Islamic Groups and their World-views and Identities: NeoTraditional Salafis and Progressive Muslims," Arab Law Quarterly, 21 (2007): 341-363.

Castells, Manuel. The Power of Identity. Oxford: Blackwell Publishers, 1997.

Echchaibi, Nabil. "From Audio Tapes to Video Blogs: The Delocalisation of Authority in Islam," Nations and Nationalism, 17: 1 (2011): 2544.

Effendy, Bahtiar. Islam and State in Indonesia. Ohio: Ohio University Press, 2004.

El-Fadl, Khalid Abou. "Islam and the Theology of Power." Available at: www.merip.org/mer/mer221/221_abu_el_fadl.html

Eickelman, Dale F. and Salvatore, Armando. "The Public Sphere and Muslim Identities," European Journal of Sociology, 43: 1 (2002): 92-115.

El-Nawawy, Mohammed and Sahar Khamis. "Divergent Identities in the Virtual Islamic Public Sphere: A Case Study of the English Discussion Forum 'Islamonline," Journal of Arab and Muslim Media Research, 5: 1 (2012).

Ess, Joseph van. The Flowering of Muslim Theology. Harvard: Harvard University Press, 2006.

Feldstein, Federico Pablo and Caroline Acosta-Alzuru, "Argentinean Jews as Scapegoat: A Textual Analysis of the Bombing of AMIA," Journal of Communication Inquiry, 27 (2003): 152-170.

Fischer, Johan. "We Shift the Channel When Mahathir Appears': The Political Internet and Censorship in Malaysia," Akademika, 75 (2009): 43-63.

Fox, Jonathan. "Religion as an Overlooked Element of International Relations," International Studies Review, 3: 3 (2001): 53-73.

Godlas, Alan. Sufism's Many Paths. Georgia: University of Georgia Press, 2000.

Harjanto, N.T.B. Islam and Liberalism in Contemporary Indonesia: The Political Ideas of Jaringan Islam Liberal (the Islam Liberal Network), MA Thesis, Ohio University, 2003.

Hasan, Noorhaidi. "The Salafi Movement in Indonesia: Transnational Dynamics and Local Development," Comparative Studies of South Asia, Africa and the Middle East, 27: 1 (2007): 83-94.

Hashim, Noor Hazarina, Jamie Murphy, and Nazlida Muhamad Hashim. "Islam and Online Imagery on Malaysian Tourist Destination Websites," Journal of Computer-Mediated Communication, 12 (2007): 1082-1102. 
Hendelman-Baavur, Liora. "Promises and Perils of Weblogistan: Online Personal Journals and the Islamic Republic of Iran," MERIA: The Middle East Review of International Affairs, June 2007.

Hill, David and Krishna Sen, Krishna. Internet in Indonesia's new democracy. London: RoutledgeCurzon, 2008.

. "Netizens in Combat: Conflict on the Internet in Indonesia," Asian Studies Review, 26: 2 (2002): 165-187.

-------. "Wiring the Warung to Global Gateways: The Internet in Indonesia," Indonesia, 63 (1997): 67-89.

Hlavacova, Simona. "US-based Islamist Network: Presence in Cyberspace and Online Projects," Masaryk University Journal of Law and Technology, 1: 2 (2007).

Ho, Shirley S., Waipeng Lee and Shahiraa Sahul Hameed. "Muslim Surfers on the Internet: Using the Theory of Planned Behaviour to Examine the Factors Influencing Engagement in Online Religious Activities, New Media Society, 10: 1 (2008): 93-113.

Ho, Wai-Yip. "Islam, China and the Internet: Negotiating Residual Cyberspace between Hegemonic Patriotism and Connectivity to the Ummah," Journal of Muslim

Minority Affairs, 30: 1 (2010): 63-79.

Hojsgaard, M. and M. Warburg, eds. Religion in Cyberspace. London: Routledge, 2004.

Hooker, Virginia M. "Developing Islamic Argument for Change through "Liberal Islam," Islamic perspectives on the New Millennium, ed. Amin Saikal and Virginia M. Hooker. Singapore: Institute of Southeast Asian Studies, 2004.

Hosen, Nadirsyah. "Online Fatwa in Indonesia: From Fatwa Shopping to Googling a Kiai,' Expressing Islam, Religious Life and Politics in Indonesia, ed. Greg Fealy and Sally White. Singapore: ISEAS, 2008.

Howard, Philip N. and Muzammil M. Hussain. Democracy's Fourth Wave? Digital Media and the Arab Spring. Oxford: Oxford University Press, 2013.

Hui, Jennifer Yang. "The Internet in Indonesia: Development and Impact of Radical Websites,' Studies in Conflict \& Terrorism, 33: 2 (2010): 171-191.

International Crisis Group. "Indonesia Backgrounder: Why Salafism and Terrorism Mostly Don't Mix', Asia Report, 83 (2004).

Janbek, Dana. "The Use of the Internet as a Communication Medium by Extremist Muslim Groups: A Content Analysis of Websites". Open Access Dissertations (2009). Available at: http://scholarlyrepository.miami.edu/oa_dissertations/273

Karagiannis, E and C. McCauley. "Hizb ut-Tahrir al-Islami: Evaluating the Threat Posed by a Radical Islamic Group that Remains Nonviolent," Terrorism and Political Violence, 18 (2006): 315-334. 
Karagiannis, E. "Political Islam in Uzbekistan: Hizb ut-Tahrir al-Islami," Europe-Asia Studies, 58: 2 (2006): 261-280.

Karim, Abdul Gaffar. "Jamaah Shalahuddin: Islamic Student Organization in Indonesia's New Order," The Flinders Journal of History and Politics, 23 (2006): 34-56.

Keene, Shima D. "Terrorism and the Internet: A Double-edged Sword," Journal of Money Laundering Control, 14: 4 (2011): 359-370.

Kenney, Michael. "Beyond the Internet: Mētis, Techne, and the Limitations of Online Artifacts for Islamist Terrorists," Terrorism and Political Violence, 22: 2 (2010): 177-197.

Khamis, Khamis and Katherine Vaughn. "Cyberactivism in the Egyptian Revolution: How Civic Engagement and Citizen Journalism Tilted the Balance," Arab Media and Society, 14 (2011). Available at: http://www.arabmediasociety.com/?article=769

Khatib, Lina. "Communicating Islamic Fundamentalism as Global Citizenship," Journal of Communication Inquiry, 27: 4 (2003): 389409.

Kluver, Randolph and Pauline Hope Cheong. "Technological Modernization, the Internet and Religion in Singapore," Journal of Computer-Mediated Communication, 12 (2007): 1122-1142.

Kort, Alexis. "Dar-al-cyber Islam: Women, Domestic Violence and the Islamic Reformation on the World Wide Web," Journal of Muslim Minority Affairs, 25: 3 (2005): 363-383.

LaSalle, Linda A. "Exploring Campus Intolerance: A Textual Analysis of Comments concerning Gay, Lesbian and Bisexual People," A paper presented at the Meeting of the American Educational Research Association, San Francisco, April 1992.

Larsen, Elena. "Wired Churches, Wired Temples: Taking Congregations and Missions into Cyberspace," Pew Internet and American Life Project, (2000): 1-22.

Larsson, Göran. "The Death of a Virtual Muslim Discussion Group: Issues and Methods in Analyzing Religion on the Net," Online-Heidelberg Journal of Religions on the Internet, 1: 1 (2005).

Lim, Merlyna. "Islamic Radicalism and anti-Americanism in Indonesia: The Role of the Internet," Policy Studies, 18 (2005).

. "The Polarization of Identity through the Internet and the Struggle for Democracy in Indonesia," Electronic Journal of Communication/La Revue Electronique de Communication, 14: 3-4 (2004).

-------. "The Internet, Social Networks, and Reform in Indonesia," Contesting Media Power: Alternative Media in a Networked World, ed. N. Couldry and J. Curran. London: Rowan \& Littlefield, 2003. 
--------. "From War-net to Net-war: The Internet and Resistance Identities in Indonesia," International Information \& Library Review, 35 (2003): 233-248.

-------. "Cyber-civic Space in Indonesia," International Development and Planning Review, 24: 4 (2002): 383-400.

Mahdawi, Pardis. "Meeting, Mating, and Cheating Online in Iran," ISIM Review, 19 (2007).

Mandaville, Peter. "Reimagining the Ummah? Information Technology and the Changing Boundaries of Political Islam," Islam Encountering Globalization, ed. Ali Mohammadi. London: RoutledgeCurzon, 2002.

Global Political Islam. London: Routledge, 2007.

--------. "Reimagining Islam in Diaspora: The Politics of Mediated Community," International Communication Gazette, 63: 169 (2001).

Martin, R. C., M. R. Woodward, and D. S. Atmaja. Defenders of Reason in Islam: Mu'tazilism from Medieval School to Modern Symbol. Oxford: Oneworld Publications, 1997.

Martin, Patrick and Sean Phelan. "Representing Islam in the Wake of September 11: A Comparison of US Television and CNN Online Message Board Discourses," Prometheus: Critical Studies in Innovation, 20: 3 (2002): 263-269.

Marty, Martin E. and Appleby, R. Scott. Fundamentalism Observed. Chicago: The University of Chicago Press, 1991.

Mazrui, Ali and Alaim Mazrui. "The Digital Revolution and the New Reformation," Harvard International Review, 23: 1 (2001): 52-55.

Mernissi, Fatima. "The Satellite, the Prince, and Shaherazad: Women as Communicators in Digital Islam," On Shifting Ground: Muslim Women in the Global Era, ed. F. Nouraie-Simone. New York: The Feminist Press, 2005.

Michael, George. "Adam Gadahn and Al-Qaeda's Internet Strategy," Middle East Policy, 16: 3 (2009): 135-152.

Mishra, Smeetha and Gaby Semaan. "Islam in Cyberspace: South Asian Muslims in America Log In," Journal of Broadcasting \& Electronic Media, 54: 1 (2001): 87-101.

Momen, Moojan. An Introduction to Shi'i Islam: The History and Doctrines of Twelve. Yale: Yale University Press, 1985.

Nisa, Eva F. "The Internet Subculture of Indonesian Face-veiled Women," International Journal of Cultural Studies, 16: 3 (2013): 241-255.

Noorhaidi. "Laskar Jihad: Islam, Militancy and the Quest for Identity in post-New Order Indonesia," PhD Dissertation, The University of Utrecht, 2005. 
Nurdin, Ahmad Ali. "Islam and State: A Study of the Liberal Islamic Network in Indonesia 1999-2004," New Zealand Journal of Asian Studies, 7: 2 (2005): 20-39.

Poole, Elizabeth. "Networking Islam: The Democratising Potential of New Technologies in

Relation to Muslim Communities," The Public, 9: 1 (2002): 51-64.

Rheingold, Howard. The Virtual Community. New York: Addison-Wesley, 2000.

Sait, Sadiq M., et. al. "Impact of Internet Usage in Saudi Arabia: A Social Perspective," International Journal of Information Technology and Web Engineering, 2: 2 (2007).

Schroeder, R., N. Heather, and R.M. Lee. "The Sacred and the Virtual: Religion in Multi-user Virtual Reality," Journal of ComputerMediated Communication, 4: 2 (1998).

Sisler, Vit. "The Internet and the Construction of Islamic Knowledge in Europe," Masaryk University Journal of Law and Technology, 1: 2 (2007).

Stark, Rodney. "Secularization, R.I.P.," Sociology of Religion, 60: 3 (1999): 249-273.

Taji-Farouki. "Islamists and the Threat of Jihad: Hizb al-Tahrir and alMuhajiroun on Israel and the Jews," Middle Eastern Studies, 36: 1 (2000): 21-46.

Thompson, John B. The Media and Modernity: A Social Theory of the Media. London: Polity Press, 1999.

Turner, Bryan S. "Cosmopolitan Virtue: On Religion in a Global Age," European Journal of Social Theory, 4: 2 (2001): 131-152.

Watt, Montgomery. Free-Will and Predestination in Early Islam. London: Luzac \& Co., 1948.

Weber, Max. The Sociology of Religion. Boston: Beacon Press, 1964.

Wheeler, Deborah L. The Internet in the Middle East: Global Expectations and Local Imaginations in Kuwait. Albany: State University of New York Press, 2006.

Wiktorowicz, Quintan. "The New Global Threat: Transnational Salafis and Jihad," Middle East Policy, 8: 4 (2001): 18-38.

-------. "Anatomy of the Salafi Movement," Studies in Conflict and Terrorism, 29 (2006): 207-239.

Wollaston, Arthur N. The Sunnis and Shias. Montana: Kessinger Publishing, 2005.

Zweiri, Mahjoob and Emma Murphy. The New Arab Media: Technology, Image and Perception. Ithaca: Ithaca Press, 2010. 